\title{
Article \\ Effect of Two-Stage Cooling on the Microstructure and Tribological Properties of Steel-Copper Bimetals
}

\author{
Yuanyuan Kang ${ }^{1}$, Guowei Zhang ${ }^{1}$, Zhaojie Wang ${ }^{1}$, Hong $\mathrm{Xu}^{1, *}$ and An Wan ${ }^{2}$ \\ 1 School of Material Science and Engineering, North University of China, Taiyuan 030051, China; \\ kangyy469627632@163.com (Y.K.); 20030358@nuc.edu.cn (G.Z.); wzj1997vip@163.com (Z.W.) \\ 2 Beijing North Hengli Technology Development Co., Ltd., Beijing 100070, China; wanna93@163.com \\ * Correspondence: xuhong@nuc.edu.cn
}

check for updates

Citation: Kang, Y.; Zhang, G.; Wang, Z.; Xu, H.; Wan, A. Effect of Two-Stage Cooling on the Microstructure and Tribological Properties of Steel-Copper Bimetals. Materials 2022, 15, 492. https:// doi.org/10.3390/ma15020492

Academic Editor: Andrea Di Schino

Received: 30 November 2021

Accepted: 4 January 2022

Published: 10 January 2022

Publisher's Note: MDPI stays neutral with regard to jurisdictional claims in published maps and institutional affiliations.

Copyright: (c) 2022 by the authors. Licensee MDPI, Basel, Switzerland. This article is an open access article distributed under the terms and conditions of the Creative Commons Attribution (CC BY) license (https:// creativecommons.org/licenses/by/ $4.0 /)$.

\begin{abstract}
In this paper, the solid-liquid composite method is used to prepare the steel-copper bimetal sample through two-stage cooling process (forced air cooling and oil cooling). The relationship between the different microstructures and friction properties of the bimetal copper layer is clarified. The results show that: the friction and wear parameters are $250 \mathrm{~N}$, the speed is $1500 \mathrm{r} / \mathrm{min}(3.86 \mathrm{~m} / \mathrm{s})$, the friction coefficient fluctuates in the range of $0.06-0.1$, and the lowest point is 0.06 at $700{ }^{\circ} \mathrm{C}$. The microstructure of the copper layer was $\alpha-\mathrm{Cu}, \delta, \mathrm{Cu}_{3} \mathrm{P}$, and $\mathrm{Pb}$ phases, and $\mathrm{Pb}$ was free between $\alpha-\mathrm{Cu}$ dendrites. When the solidification temperature is $900{ }^{\circ} \mathrm{C}$, the secondary dendrite of $\alpha$-Cu develops. With the decrease temperature, the growth of primary and secondary dendrites gradually tends to balance at $700{ }^{\circ} \mathrm{C}$. During the wear process, $\mathrm{Pb}$ forms a self-lubricating film uniformly distributed on the surface of $\alpha-\mathrm{Cu}$, and the $\mathrm{Cu}_{3} \mathrm{P}$ and $\delta$ phases are distributed in the wear mark to increase $\alpha-\mathrm{Cu}$ wear resistance.
\end{abstract}

Keywords: EN CC497K; steel-copper bimetal; solidifies; friction and wear

\section{Introduction}

Bimetallic materials are composed of two or more metals with different properties that are combined in a layered manner to form a metallurgical interface [1-3]. Steel-copper bimetallic materials are widely used in the axial piston pump [4,5], and copper-based alloys, as one component of the bimetal, play an unreplaceable role due to their outstanding selflubricating properties [6,7]. The EN CC497K alloy exhibits excellent tribological properties due to the high $\mathrm{Pb}$ content [8-10]. Therefore, in this paper, we select EN CC497K as the research object of the bimetallic copper layer.

The steel-copper bimetal bonding methods include: solid-liquid casting, electron beam welding, explosive welding, semi-solid rolling, selective laser melting, etc. [11-14]. The microstructure of the copper layer produced by traditional casting processes show a coarse reticular dendritic structure, which leads to intergranular segregation and negative segregation, and hot-cracking in metal materials [15]; all of these defects severely restrict the tribological performances of materials. Numerous studies have reported that incorporating additives, such as graphite, molybdenum disulfide, titanium diboride, nickel, and silver powder, into the alloy matrix can improve the anti-wear and mechanical properties of the lubricating alloy [16-21]. However, the structure of the bimetallic copper layer formed at room temperature is still coarse, the hardness of the copper layer is low, and the wear resistance is insufficient.

The purpose of this work is to accelerate the solidification cooling rate during solidliquid forming by forced air cooling, refine the $\alpha$-Cu dendritic, and preserve the copper layer structure at different solidification temperatures through oil quenching. The microstructures under different solidification temperatures are discussed, and the lubrication mechanism of copper with different microstructure morphologies is proposed in combination with friction and wear properties. 


\section{Experimental Procedure}

\subsection{Material and Characterizations}

Using the solid-liquid casting method to prepare steel-copper bimetal samples, the preheating temperature of the steel matrix was $1150 \pm 30^{\circ} \mathrm{C}$ and the copper alloy smelting temperature was $1200 \pm 20^{\circ} \mathrm{C}$. The copper alloy was subsequently poured into the preheated steel matrix to form a bimetallic composite interface.The composition of the steel after casting is $0.42 \% \mathrm{C}, 0.21 \% \mathrm{Si}, 0.68 \% \mathrm{Mn}, 0.04 \% \mathrm{Cr}$, and $0.02 \% \mathrm{Ni}$ (wt. \%). The grade of copper alloy is EN CC497K, and the actual element content obtained is shown in Table 1, which were detected by the German SPECTRO-MAXx spectrometer.

Table 1. Chemical composition of the matrix material (wt.\%).

\begin{tabular}{ccccccc}
\hline Copper Layer & $\mathbf{P b}$ & Sn & $\mathbf{P}$ & $\mathbf{N i}$ & $\mathbf{Z n}$ & $\mathbf{C u}$ \\
\hline EN CC497K & 18.35 & 4.88 & 0.08 & 1.83 & 1.75 & Bal. \\
\hline
\end{tabular}

Figure 1 is a schematic diagram of the steel-copper bimetal two-stage cooling device. After the solid-liquid forming, the bimetal is placed in the position of the red solid line in Figure $1 \mathrm{a}$ for forced air cooling. The copper liquid cooling temperature is monitored by a temperature sensor: when the solidification temperature reaches the preset temperature (400-900 ${ }^{\circ} \mathrm{C}$ ), the bimetal sample is lowered to the position of the red dotted line, as through cooling the oil rapidly solidification occurs to obtain bimetal samples.

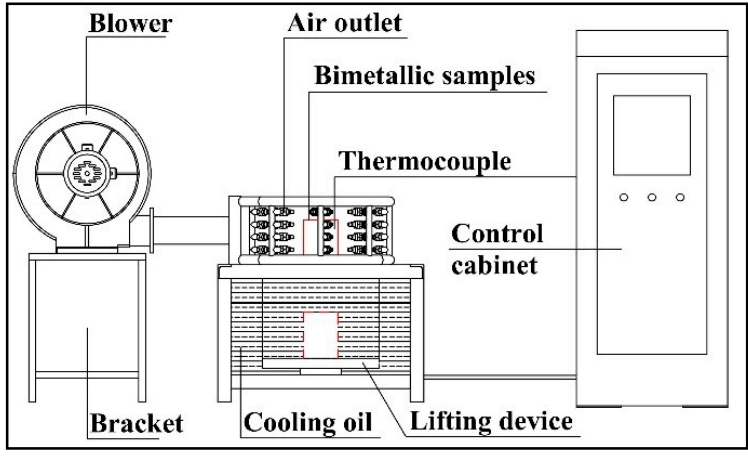

(a)

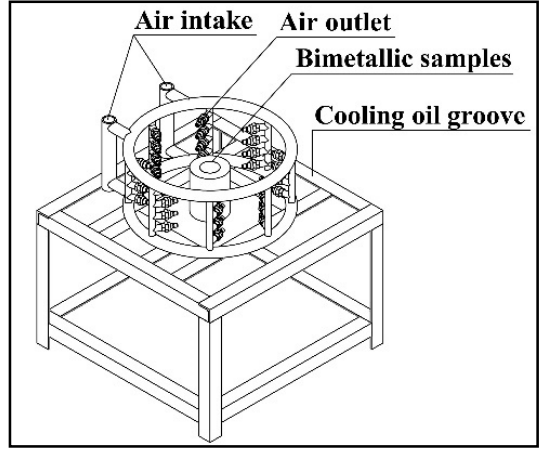

(b)

Figure 1. Steel-copper bimetal two-stage cooling device. (a) Device control module; (b) the steelcopper bimetal placement.

The aim of the experiments was to identify a solidification temperature that avoids cracking between the steel and copper interface, with a desirable microstructure to optimize friction and wear properties. Solidification temperatures of $400{ }^{\circ} \mathrm{C}, 500{ }^{\circ} \mathrm{C}, 600{ }^{\circ} \mathrm{C}, 700{ }^{\circ} \mathrm{C}$, $800{ }^{\circ} \mathrm{C}$, and $900{ }^{\circ} \mathrm{C}$ were investigated. Figure 2 shows the microstructure of the steelcopper bimetal interface at different solidification temperatures: the bimetal copper layer is composed of $\alpha-\mathrm{Cu}$ and $\mathrm{Pb}$, and $\mathrm{Pb}$ and $\mathrm{Cu}$ are not mutually soluble at all, being free on the $\mathrm{Cu}$ matrix. With the decrease in the solidification temperature, $\mathrm{Pb}$ changes to varying degrees, and the tribological properties of the copper layer also change. The steel-copper interface prepared formed a metallurgical bond without defects, as shown in Figure 2c. 

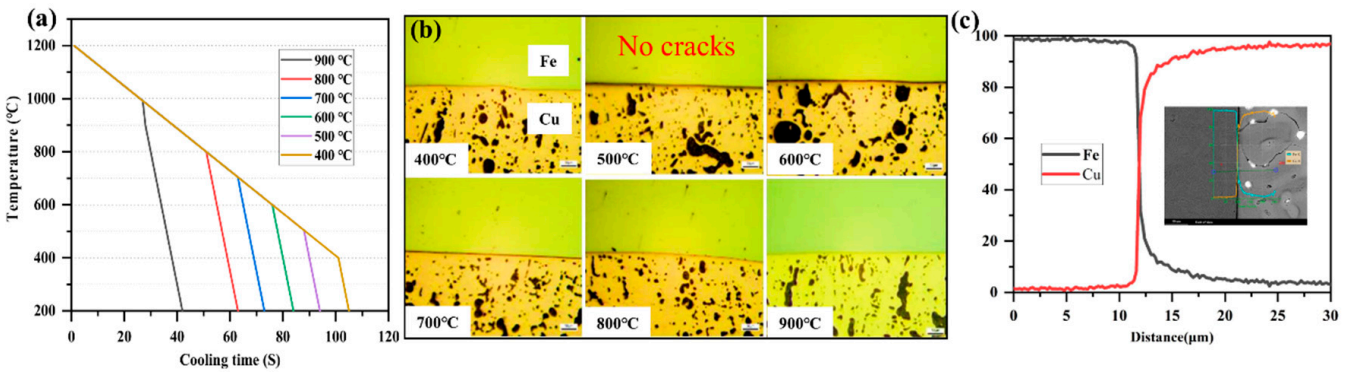

Figure 2. The bimetal rapid solidification test parameters and steel-copper interface. (a) Test parameters of the steel-copper bimetal; (b) OM microstructure; and (c) $\mathrm{Fe}-\mathrm{Cu}$ atomic interdiffusion.

\subsection{Test Method}

The samples size and sampling method are shown in Figure 3. In the actual working conditions of the plunger pump cylinder, the friction surface of the plunger hole copper layer was $2 \mathrm{~mm}$ from the interface thickness, so the friction and wear copper layer was taken as $2 \mathrm{~mm}$ during the sampling process. Two samples were taken from symmetrical positions, and they were used for microstructure and friction tests.
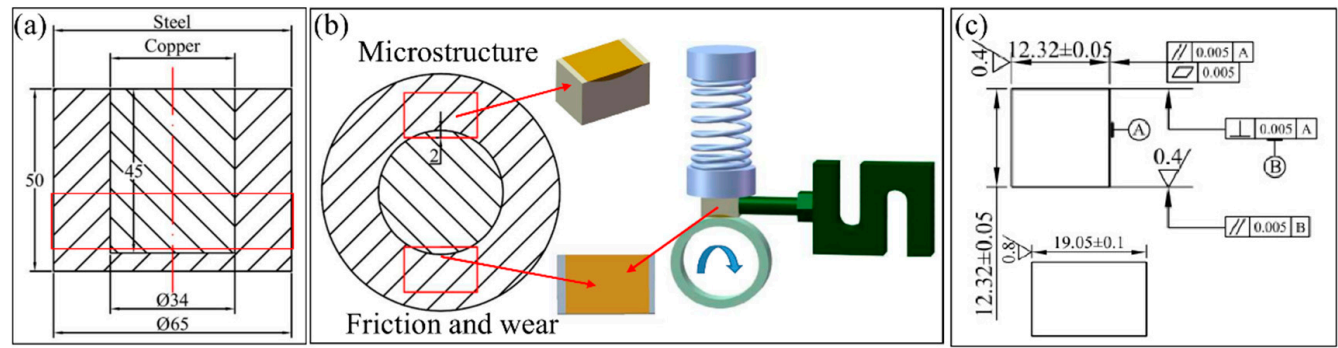

Figure 3. Bimetal samples size and sampling method. (a) Bimetal size before sampling; (b) microstructure and friction sampling location; and (c) size of the samples.

According to the specification of GB/T 12444-2006, the friction and wear test was carried out on an MRH-3 high-speed ring-on-block wear tester. The testing of the oil-rich working conditions was performed in a vehicle general lubricating oil of $15 \mathrm{~W}-40$. The material of the friction counter ring was 534A99, and its surface roughness was $\mathrm{Ra}=0.6$, with the copper layers of the samples having the same surface roughness. The specific working conditions and methods used in this article were: the test load was $250 \mathrm{~N}$, the speed was $1500 \mathrm{r} / \mathrm{min}(3.86 \mathrm{~m} / \mathrm{s})$, and the friction time was $20 \mathrm{~min}$. The wear test is shown schematically in Figure 3b; in the oil-rich condition, lubricating oil continuously covered the contact surface of the friction pair during the test.

The friction coefficient was automatically acquired and recorded by the tester, the wear volume $\left(\mathrm{V}, \mathrm{mm}^{3}\right)$ was measured by a $2 \mathrm{D}$ surface profiler, and the wear rate was cal-culate by the following equation:

$$
\text { Wear rate }=\mathrm{V} /(\mathrm{F} \cdot \mathrm{L})
$$

where $\mathrm{F}$ is the load, and the $\mathrm{L}$ is the total distance duringthe friction test.

The hardness test of copper layer was carried out with a Brinell hardness tester, with the test parameters being $2.5 \mathrm{kN}$ load force and the holding time $30 \mathrm{~s}$. The copper alloy was etched with $\mathrm{NH}_{3} \cdot \mathrm{H}_{2} \mathrm{O}: \mathrm{H}_{2} \mathrm{O}_{2}=1: 5$, and the steel was etched with a $5 \%$ nitric acid alcohol solution. A Zeiss Smartzoom 5 optical microscope (OM) was used to observe of the bimetallic samples. The copper alloy phase and wear scar were studied by field-emission scanning electron microscopy (SEM) operated at $20 \mathrm{kV}$ combined with energy-dispersive spectrometry (EDS). 


\section{Results and Discussion}

\subsection{Friction and Wear Properties}

Figure 4 shows the friction coefficient, wear rate and hardness of copper layers at different solidification temperatures. Figure 4 a shows the friction coefficient fluctuates in the range of $0.06-0.1$ during the change of the solidification temperature from $400{ }^{\circ} \mathrm{C}$ to $900{ }^{\circ} \mathrm{C}$, and it first decreases and then increases as the cooling temperature increases [22]. It reaches the lowest point of 0.06 at $700{ }^{\circ} \mathrm{C}$, and the friction coefficient stabilizes after $800{ }^{\circ} \mathrm{C}$. Figure $4 \mathrm{~b}, \mathrm{c}$ shows that the wear rate and hardness show an opposite trend; the wear rate gradually decreases with the increase in cooling temperature, and the hardness gradually increases.
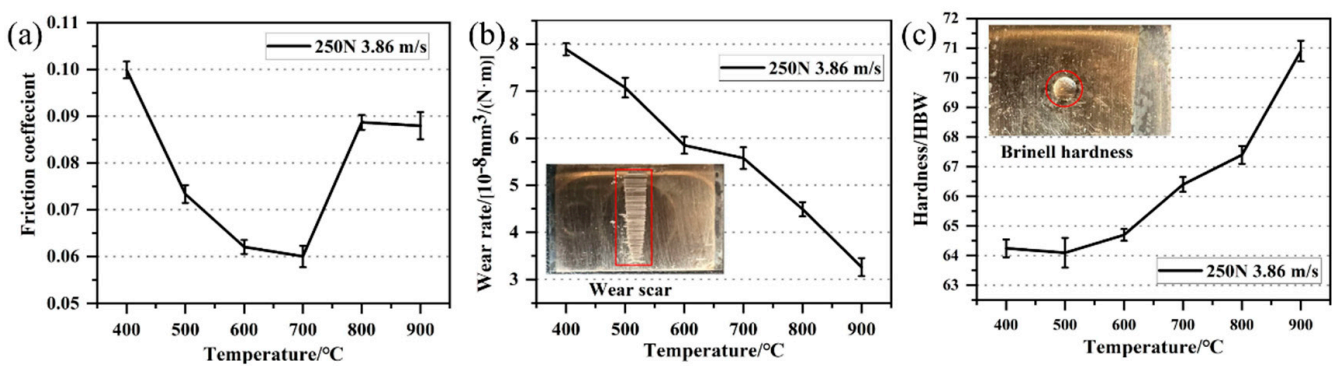

Figure 4. Copper layers properties. (a) Friction coefficient; (b) wear rate; and (c) Brinell hardness.

\subsection{Microstructure of Copper Layers}

Figure 5 shows the SEM images of copper at different temperatures. It can be seen that, with the gradual decrease in the temperature, the $\alpha-\mathrm{Cu}$ dendrite morphology in the alloy changes significantly. At $900{ }^{\circ} \mathrm{C}$, the secondary branches on the same tree trunk of the crystal growth are developed; at $800^{\circ} \mathrm{C}$, the number of secondary dendrites is evidently reduced, mostly of a short and thick morphology; at $700{ }^{\circ} \mathrm{C}$, the structure of the $\alpha$-Cu matrix forms uniform dendrites, and $\mathrm{Pb}$ is distributed among the dendrites; at $600{ }^{\circ} \mathrm{C}$ to $400{ }^{\circ} \mathrm{C}$, the primary dendrite arm spacing gradually widens.
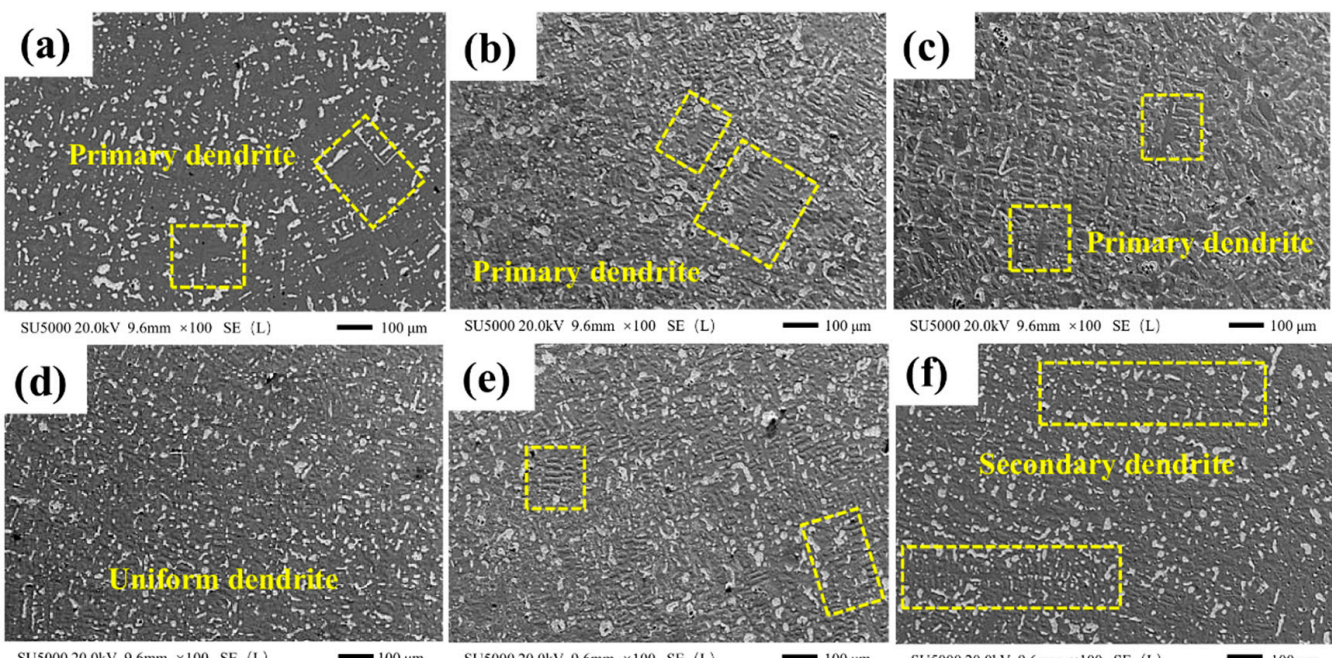

Figure 5. Copper layers dendrite morphology at different solidification temperatures. (a) $400{ }^{\circ} \mathrm{C}$, (b) $500{ }^{\circ} \mathrm{C}$, (c) $600{ }^{\circ} \mathrm{C}$, (d) $700{ }^{\circ} \mathrm{C}$, (e) $800{ }^{\circ} \mathrm{C}$, and (f) $900{ }^{\circ} \mathrm{C}$.

The high temperature provides the driving force for the dendrite growth and nucleation [23]. When the solidification temperature is high, the $\alpha-\mathrm{Cu}$ is directionally solidified under the rapid cooling, the dendrite growth is thin and long, and the secondary dendrite is developed. With the decrease in temperature, the growth of primary dendrite and secondary dendrite gradually tends to balance, reaching the best at $700{ }^{\circ} \mathrm{C}$, and the dendrite 
distribution is more uniform. With the gradual extension of the solidification, the primary dendrite arms grow gradually, until the temperature drops to $400{ }^{\circ} \mathrm{C}$, the dendrites interlace each other. During the solidification process, the low melting point $\mathrm{Pb}$ is squeezed between the dendrites, and the different $\alpha$-Cu morphologies result in different $\mathrm{Pb}$ morphologies.

Figure 6 is a statistical diagram of the number of $\mathrm{Pb}$ in the copper layer. It can be seen that the area of $\mathrm{Pb}$ is mostly concentrated within $450 \mu \mathrm{m}^{2}$, and the uniform and rounded state of $\mathrm{Pb}$ is conducive to the wear resistance of copper layer. Comparing the morphology of $\mathrm{Pb}$ at different solidification temperatures, the $\mathrm{Pb}$ particle size at $400{ }^{\circ} \mathrm{C}$ and $500{ }^{\circ} \mathrm{C}$ accounts for a larger proportion of $10 \mu \mathrm{m}^{2}$, and when the temperature exceeds $600{ }^{\circ} \mathrm{C}$, the number of $\mathrm{Pb}$ with $10-50 \mu \mathrm{m}^{2}$ is the largest. $\mathrm{Pb}$ has a face-centered cubic structure, and its shear strength is low. During friction, it can effectively reduce the friction coefficient through the self-shearing of lead between the friction pairs. In the friction direction, due to the shear force, it transfers to the surface enrichment and forms a self-lubricating Pb film that improves the friction properties of the alloy.
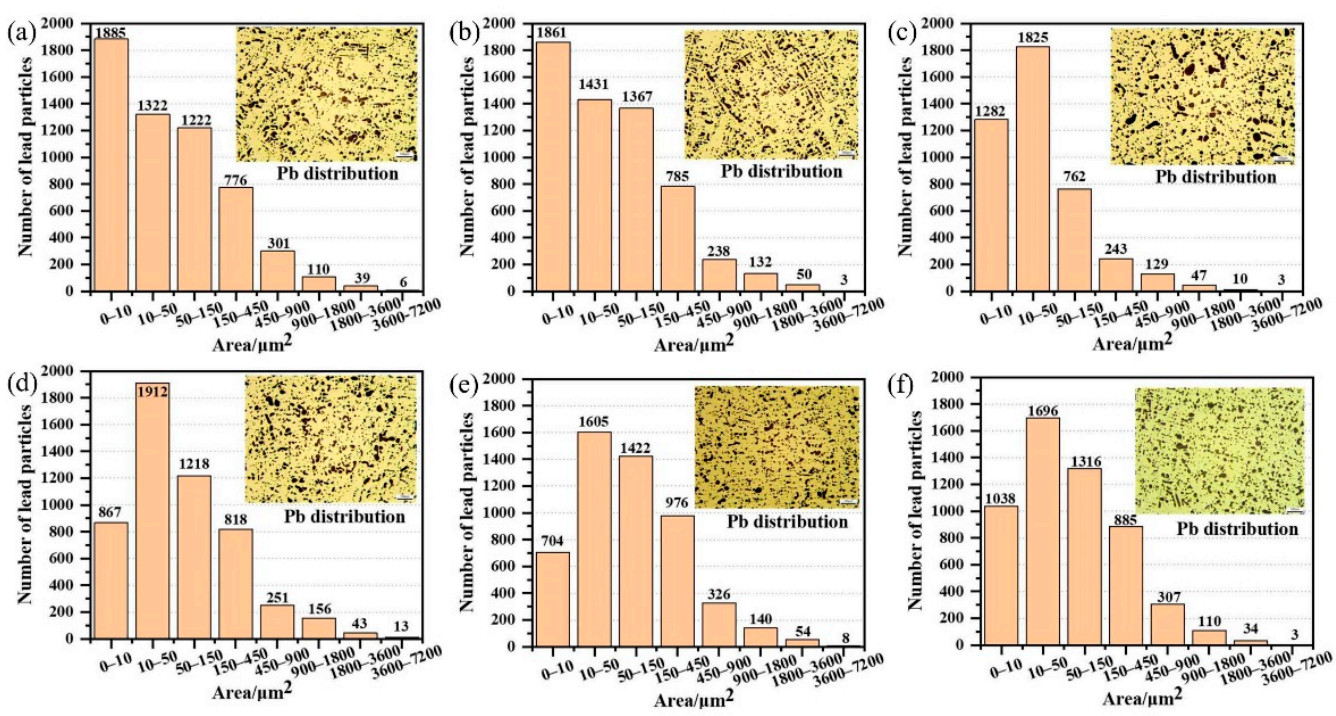

Figure 6. The copper layer Pb statistics. (a) $400{ }^{\circ} \mathrm{C}$, (b) $500{ }^{\circ} \mathrm{C}$, (c) $600{ }^{\circ} \mathrm{C}$, (d) $700{ }^{\circ} \mathrm{C}$, (e) $800{ }^{\circ} \mathrm{C}$, and (f) $900{ }^{\circ} \mathrm{C}$.

Figure 7 shows the EDS point scan of each phase in the copper layer. The structure mainly was $\alpha-\mathrm{Cu}, \delta\left(\mathrm{Cu}_{31} \mathrm{Sn}_{8}\right), \mathrm{Cu}_{3} \mathrm{P}$, and $\mathrm{Pb}$ phases. The $\alpha-\mathrm{Cu}$ matrix is soft, and $\delta$ and $\mathrm{Cu}_{3} \mathrm{P}$ are both hard phases, which can increase the surface hardness of the alloy and improve the wear resistance.

Figure 8 is the EDS surface scanning energy spectrum at different solidification temperatures. $\mathrm{Cu}$ elements are distributed throughout the entire structure, and $\mathrm{P}$ and $\mathrm{Sn}$ are distributed in the $\alpha-\mathrm{Cu}$ matrix, but the $\mathrm{Sn}$ content is relatively high above $700{ }^{\circ} \mathrm{C}$. As the solidification progresses, $\mathrm{Sn}$ and $\mathrm{P}$ elements continue to diffuse into $\mathrm{Cu}$, causing the $\delta$ and $\mathrm{Cu}_{3} \mathrm{P}$ phases in $\alpha-\mathrm{Cu}$ to change to varying degrees. Sn diffuses into $\mathrm{Cu}$ to form $(\alpha+\delta)$ peritectic structure [24], making the hard particles in the copper layer reduce, which improves the friction properties. The $\mathrm{Cu}_{3} \mathrm{P}$ phase is a hard phase, which is distributed in the $\alpha-\mathrm{Cu}$ matrix and locally enhances the wear resistance of the alloy during the wear process. 

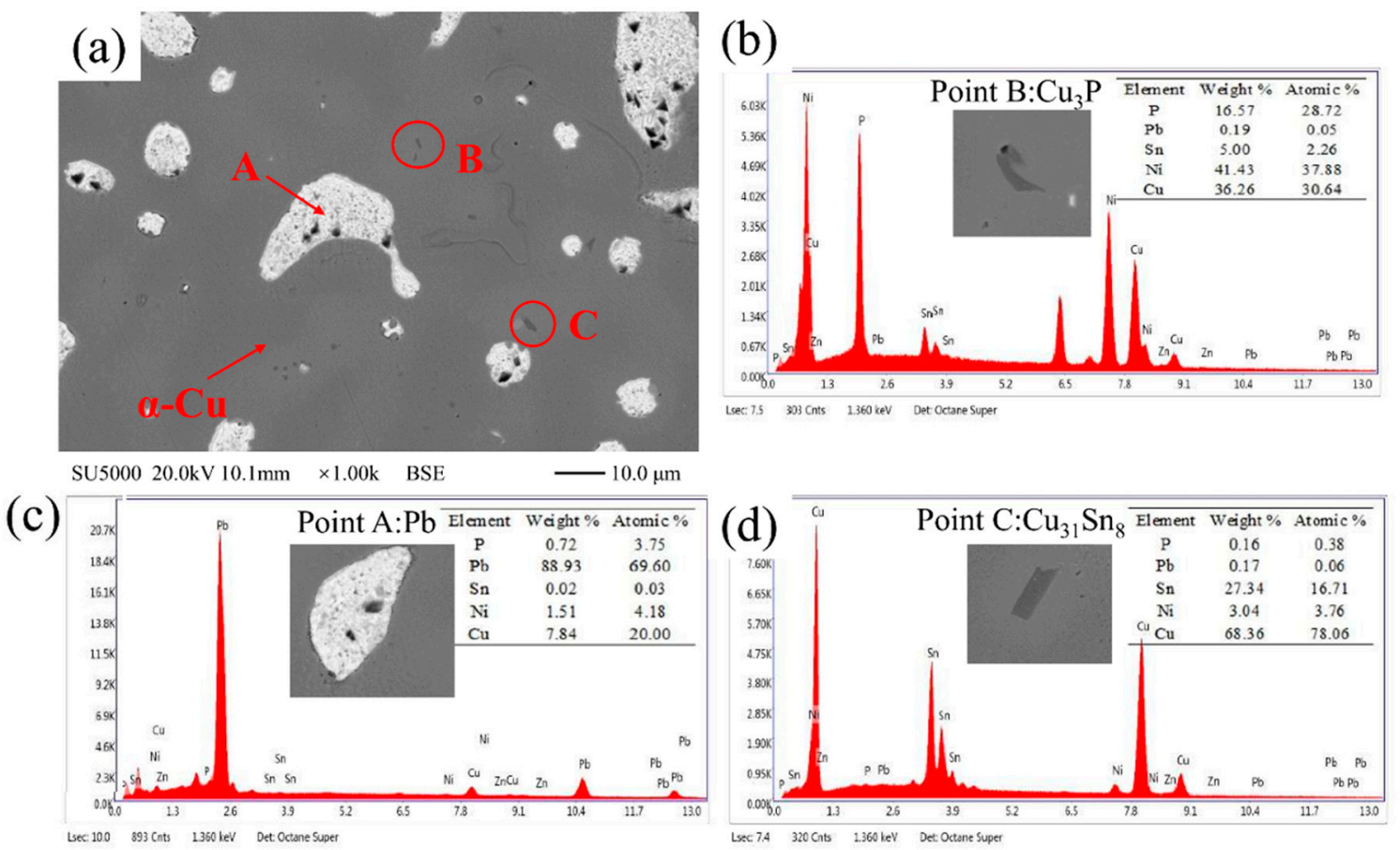

Figure 7. The copper layer phase composition. (a) BSE microstructure, (b) EDS at point B in (a), (c) EDS at point $\mathrm{A}$ in (a), and (d) EDS at point $\mathrm{C}$ in (a).
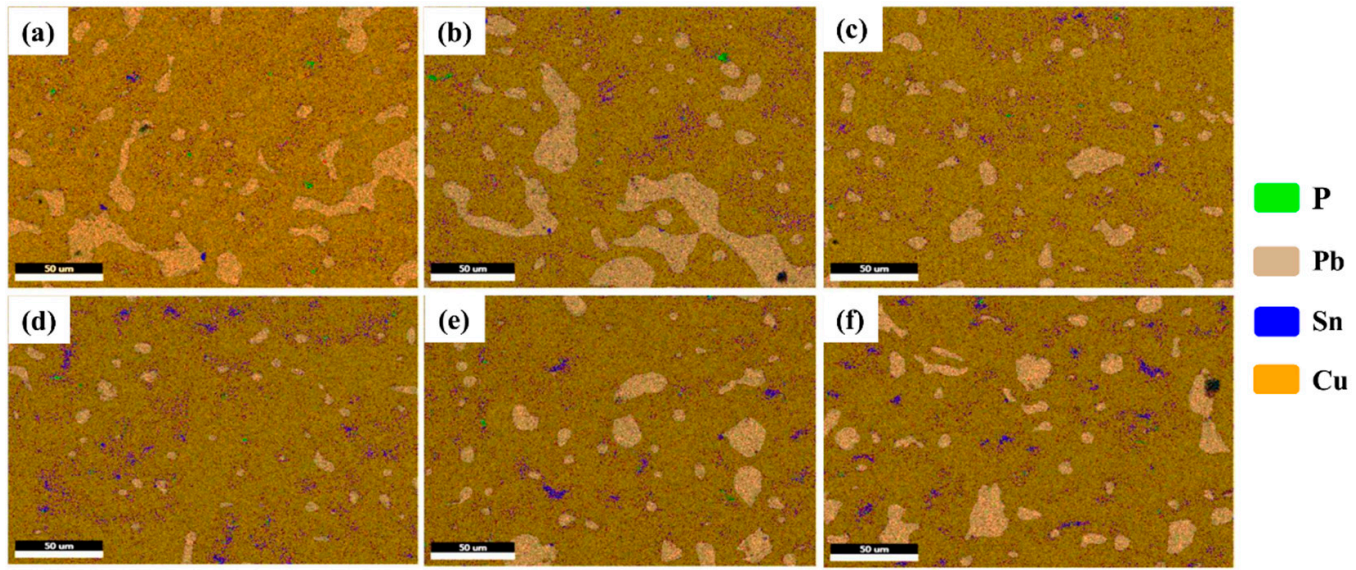

Figure 8. The distribution of elements in the copper layer at different solidification temperatures. (a) $400{ }^{\circ} \mathrm{C}$, (b) $500{ }^{\circ} \mathrm{C}$, (c) $600{ }^{\circ} \mathrm{C}$, (d) $700{ }^{\circ} \mathrm{C}$, (e) $800{ }^{\circ} \mathrm{C}$, and (f) $900{ }^{\circ} \mathrm{C}$.

\subsection{Analysis of Wear Mechanism of Copper Layer}

The wear scar of copper layer is observed in Figure 9. Under the conditions of a friction load of $250 \mathrm{~N}$ and a linear velocity of $3.86 \mathrm{~m} / \mathrm{s}$, as the solidification temperature decreases, the wear marks on the surface of the copper gradually become deeper. When the temperature is higher than $700{ }^{\circ} \mathrm{C}$, the wear surface is relatively smooth, and there are wear marks and wear debris on the substrate. The contact area between the $\alpha$-Cu matrix and the steel ring is mostly the contact between the small metal protrusions. The developed secondary dendrites can enhance the wear resistance of the $\alpha$-Cu matrix, which are not easily damaged during the wear process [25]. When the temperature is $700{ }^{\circ} \mathrm{C}$, the distribution of $\alpha-\mathrm{Cu}$ dendrites is uniform, and the soft $\mathrm{Pb}$ forms a lubricating film on the surface of the substrate, which effectively reduces the friction coefficient; the wear mechanism above $700{ }^{\circ} \mathrm{C}$ is particle wear. 

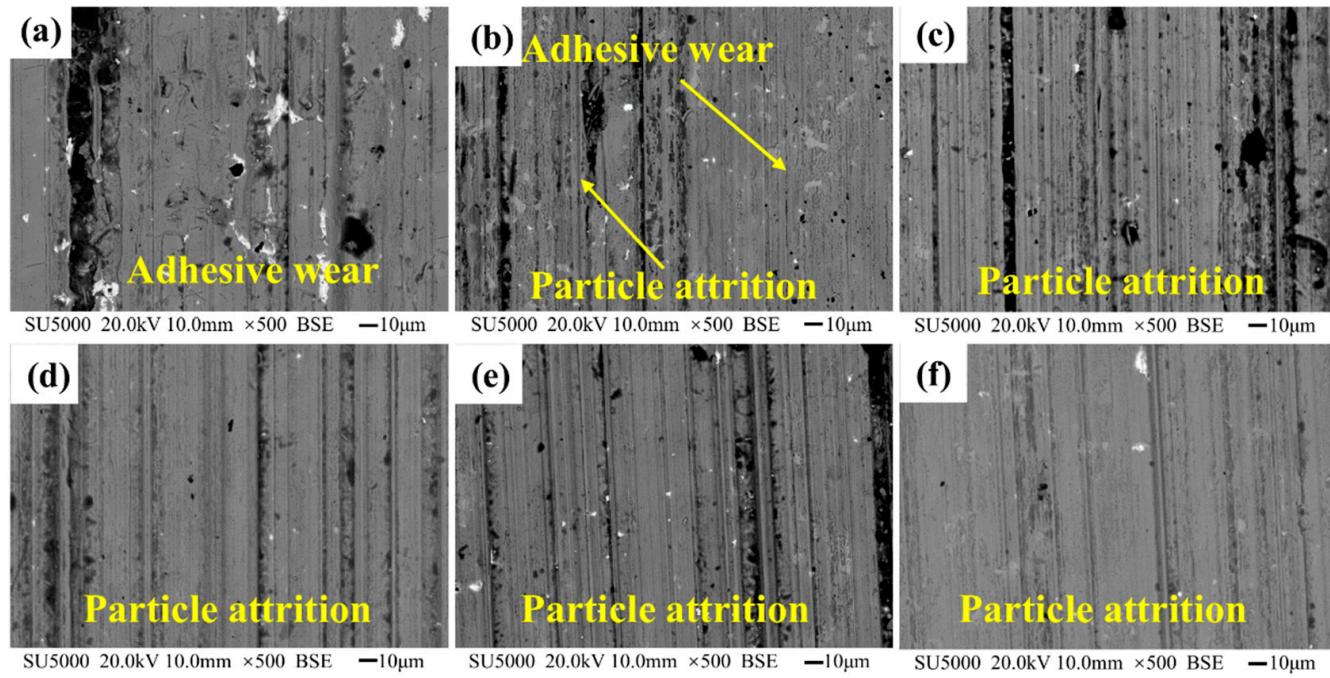

Figure 9. The copper layer wear scar morphology. (a) $400{ }^{\circ} \mathrm{C}$, (b) $500{ }^{\circ} \mathrm{C}$, (c) $600{ }^{\circ} \mathrm{C}$, (d) $700{ }^{\circ} \mathrm{C}$, (e) $800{ }^{\circ} \mathrm{C}$, and (f) $900{ }^{\circ} \mathrm{C}$.

When the temperature is lower than $600{ }^{\circ} \mathrm{C}$, the primary dendrite of $\alpha$-Cu is thickened, and the $\mathrm{Pb}$ film is gradually extruded, causing the friction coefficient to increase and causing adhesive wear. The wear intensifies with the decrease in the solidification temperature, the penetration depth of the micro-protrusions on the friction surface of the steel ring increases, the actual contact area between the friction pairs increases, and the wear is serious, resulting in an increase in the wear rate.

A surface scan on the wear surface at $700{ }^{\circ} \mathrm{C}$ is shown in Figure 10 . The $\mathrm{Pb}$ film is uniformly distributed on the $\alpha-\mathrm{Cu}$ surface, and the $\mathrm{Cu}_{3} \mathrm{P}$ and $\delta$ phases are distributed in the wear scar, indicating that it plays a role in reducing wear [26]. When the solidification temperature is $700{ }^{\circ} \mathrm{C}$, there are some liquid islands distributed inside the $\alpha-\mathrm{Cu}$ matrix; when these liquid islands solidify and nucleate, the low melting point eutectoid phase $\left(\delta+\mathrm{Cu}_{3} \mathrm{P}\right)$ is distributed around $\alpha-\mathrm{Cu}$, wrap the $\alpha-\mathrm{Cu}$ crystal grains, and part of the eutectoid phase $\left(\alpha+\delta+\mathrm{Cu}_{3} \mathrm{P}\right)$ into the $\alpha-\mathrm{Cu}$. As the solidification progresses, the remaining eutectoid phase inside the $\alpha-\mathrm{Cu}$ is retained, and finally formed in the peritectic structure with $\mathrm{Pb}$ coexisting. The $\mathrm{Pb}$ film is not easily destroyed during the wear process, which enhances the wear resistance of the copper layer.
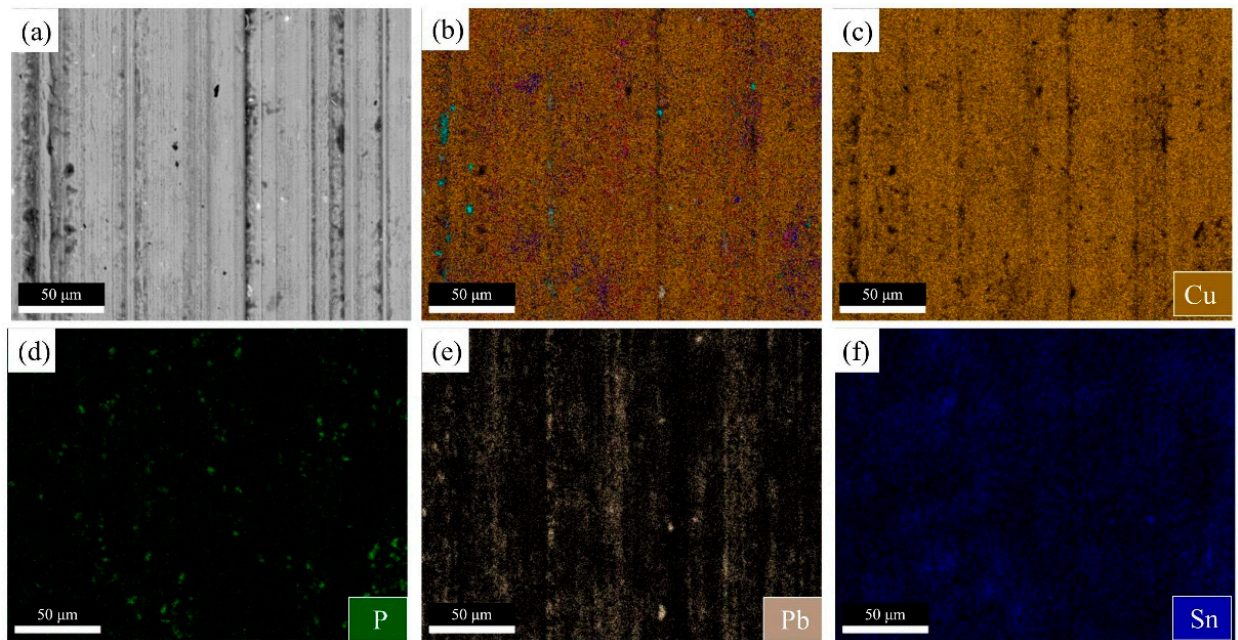

Figure 10. Map of copper layers wear scar with solidification temperature of $700{ }^{\circ} \mathrm{C}$. (a) Copper layers BSE, (b) element distribution, (c) $\mathrm{Cu},(\mathbf{d}) \mathrm{P},(\mathbf{e}) \mathrm{Pb}$, and (f) $\mathrm{Sn}$. 


\section{Conclusions}

The solid-liquid composite method was used to prepare a steel-copper bimetal sample through the two-stage cooling process (forced air cooling and oil cooling). The aim of the experiments is to identify a solidification temperature that avoids cracking between the steel and copper interface, with a desirable microstructure to optimize friction and wear properties. Solidification temperatures of $400{ }^{\circ} \mathrm{C}, 500{ }^{\circ} \mathrm{C}, 600{ }^{\circ} \mathrm{C}, 700{ }^{\circ} \mathrm{C}, 800^{\circ} \mathrm{C}$ and $900{ }^{\circ} \mathrm{C}$ were investigated, and the following conclusions are drawn:

(1) The bimetal copper layer friction and wear parameters are $250 \mathrm{~N}$, speed is $1500 \mathrm{r} / \mathrm{min}$ $(3.86 \mathrm{~m} / \mathrm{s})$, solidification temperature is $400-900{ }^{\circ} \mathrm{C}$, and the friction coefficient is $0.06-0.1$, reaching the lowest point of 0.06 at $700{ }^{\circ} \mathrm{C}$;

(2) As the solidification temperature decreases, the growth of primary and secondary dendrites gradually tends to balance at $700{ }^{\circ} \mathrm{C}$, which is lower than this temperature, and the primary dendrite arms gradually grow up. The uniform dendrite distribution makes the $\mathrm{Pb}$ distribution uniform, which is beneficial to the friction performance;

(3) The low melting point eutectoid phase $\left(\alpha+\delta+\mathrm{Cu}_{3} \mathrm{P}\right)$ is distributed around $\alpha-\mathrm{Cu}$, forming a peritectic structure coexisting with $\mathrm{Pb}$. Wearing the process, $\mathrm{Pb}$ forms a self-lubricating film uniformly distributed on the surface of $\alpha-\mathrm{Cu}$, and $\mathrm{Cu}_{3} \mathrm{P}$ and $\delta$ phases are distributed in the wear mark to increase $\alpha$-Cu wear resistance.

Author Contributions: Conceptualization, Y.K. and G.Z.; methodology, Y.K. and G.Z.; software, A.W.; validation, Z.W., Y.K. and A.W.; formal analysis, Z.W.; investigation, Y.K.; resources, H.X.; data curation, Y.K.; writing-original draft preparation, Y.K.; writing-review and editing, G.Z.; visualization, A.W.; supervision, H.X.; project administration, H.X.; funding acquisition, H.X. All authors have read and agreed to the published version of the manuscript.

Funding: This research was funded in part by the Natural Science Foundation of Shanxi Province (Grant No. 201801D121111).

Institutional Review Board Statement: Not applicable.

Informed Consent Statement: Not applicable.

Data Availability Statement: Not applicable.

Acknowledgments: The authors thank the anonymous reviewers for the constructive comments and suggestions.

Conflicts of Interest: The authors declare no conflict of interest.

\section{References}

1. Gladkovsky, S.V.; Kuteneva, S.V.; Sergeev, S.N. Microstructure and mechanical properties of sandwich copper/steel composites produced by explosive welding. Mater. Charact. 2019, 154, 294-303. [CrossRef]

2. Tan, C.; Zhou, K.; Ma, W.; Min, L. Interfacial characteristic and mechanical performance of maraging steel-copper functional bimetal produced by selective laser melting based hybrid manufacture. Mater. Des. 2018, 155, 77-85. [CrossRef]

3. Hajjari, E.; Divandari, M.; Razavi, S.H.; Emami, S.M.; Homma, T.; Kamado, S. Dissimilar joining of $\mathrm{Al} / \mathrm{Mg}$ light metals by compound casting process. J. Mater. Sci. 2011, 46, 6491-6499. [CrossRef]

4. Parveez, B.; Wani, M.F. Tribological behaviour of nano-zirconia reinforced iron-based self-lubricating composites for bearing applications. Tribol. Int. 2021, 159, 106969. [CrossRef]

5. Hammes, G.; Schroeder, R.; Binder, C.; Klein, A.N.; de Mello, J.D.B. Effect of double pressing/double sintering on the sliding wear of self-lubricating sintered composites. Tribol. Int. 2014, 70, 119-127. [CrossRef]

6. Equey, S.; Houriet, A.; Mischler, S. Wear and frictional mechanisms of copper-based bearing alloys. Wear 2011, 273, 9-16. [CrossRef]

7. Robbiola, L.; Blengino, J.-M.; Fiaud, C. Morphology and mechanisms of formation of natural patinas on archaeological Cu-Sn alloys. Corros. Sci. 1998, 40, 2083-2111. [CrossRef]

8. Zheng, Z.; Chen, Y.; Zhang, M.; Liu, J.; Yang, A.; Chen, L.; Yang, Q.; Lou, D.; Liu, D. Fabrication of carbon nanotubes/Cu composites with orthotropic mechanical and tribological properties. Mater. Sci. Eng. A-Struct. Mater. Prop. Microstruct. Process. 2021, 804, 140788. [CrossRef]

9. Zhou, H.; Yao, P.; Gong, T.; Xiao, Y.; Zhang, Z.; Zhao, L.; Fan, K.; Deng, M. Effects of ZrO2 crystal structure on the tribological properties of copper metal matrix composites. Tribol. Int. 2019, 138, 380-391. [CrossRef] 
10. Zhang, P.; Zhang, L.; Wu, P.; Cao, J.; Shijia, C.; Wei, D.; Qu, X. Effect of carbon fiber on the braking performance of copper-based brake pad under continuous high-energy braking conditions. Wear 2020, 458-459, 203408. [CrossRef]

11. Song, D.; Wang, T.; Jiang, S.; Zhang, L. Microstructure and Mechanical Properties of Copper-steel Laminated and Sandwich Joints Prepared by Electron Beam Welding. J. Mater. Eng. Perform. 2020, 29, 4251-4259. [CrossRef]

12. Zhang, H.; Jiao, K.X.; Zhang, J.L.; Liu, J. Comparisons of the microstructures and micro-mechanical properties of copper/steel explosive-bonded wave interfaces. Mater. Sci. Eng. A Struct. Mater. Prop. Microstruct. Process. 2019, 756, 430-441. [CrossRef]

13. Zhang, Y.; Liu, J.; Fu, Y.; Jie, J.; Lu, Y.; Guo, Q.; Wang, T.; Li, T. Microstructure and Fabrication of Cu-Pb-Sn/Q235 Laminated Composite by Semi-Solid Rolling. Metals 2018, 8, 722. [CrossRef]

14. Zhang, G.; Kang, Y.; Wang, M.; Xu, H.; Jia, H. Atomic diffusion behavior and diffusion mechanism in Fe-Cu bimetal casting process studied by molecular dynamics simulation and experiment. Mater. Res. Express 2020, 7, 096519. [CrossRef]

15. Shaik, M.A.; Golla, B.R. Development of highly wear resistant $\mathrm{Cu}-\mathrm{Al}$ alloys processed via powder metallurgy. Tribol. Int. 2019, 136, 127-139. [CrossRef]

16. Sam, M.; Radhika, N. Development of functionally graded $\mathrm{Cu}-\mathrm{Sn}-\mathrm{Ni} / \mathrm{Al}_{2} \mathrm{O}_{3}$ composite for bearing applications and investigation of its mechanical and wear behavior. Part. Sci. Technol. 2019, 37, 220-231. [CrossRef]

17. Radhika, N.; Teja, K.; Rahul, K.; Shivashankar, A. Fabrication of Cu-Sn-Ni /SiC FGM for Automotive Applications: Investigation of its Mechanical and Tribological Properties. Silicon 2018, 10, 1705-1716. [CrossRef]

18. Liu, J.; Yang, S.; Xia, W.; Jiang, X.; Gui, C. Microstructure and wear resistance performance of Cu-Ni-Mn alloy based hardfacing coatings reinforced by WC particles. J. Alloys Compd. 2016, 654, 63-70. [CrossRef]

19. Jha, P.; Gautam, R.K.; Tyagi, R. Friction and wear behavior of $\mathrm{Cu}-4 \mathrm{wt}$ \%Ni-TiC composites under dry sliding conditions. Friction 2017, 5, 437-446. [CrossRef]

20. Xie, M.; Wu, C.; Zhou, S.; Jin, J.; Zhao, S.; Chen, D. TiB2- and Fe2P with nanotwins-reinforced Cu-based immiscible composites fabricated by selective laser melting: Formation mechanism and wear behavior. J. Alloys Compd. 2021, 864, 158716. [CrossRef]

21. Zou, C.; Chen, Z.; Kang, H.; Wang, W.; Li, R.; Li, T.; Wang, T. Study of enhanced dry sliding wear behavior and mechanical properties of $\mathrm{Cu}-\mathrm{TiB} 2$ composites fabricated by in situ casting process. Wear 2017, 392, 118-125. [CrossRef]

22. Senatore, A.; Risitano, G.; Scappaticci, L.; D'Andrea, D. Investigation of the Tribological Properties of Different Textured Lead Bronze Coatings under Severe Load Conditions. Lubricants 2021, 9, 34. [CrossRef]

23. Dong, B.W.; Wang, S.H.; Dong, Z.Z.; Jie, J.C.; Wang, T.M.; Li, T.J. Novel insight into dry sliding behavior of Cu-Pb-Sn in-situ composite with secondary phase in different morphology. J. Mater. Sci. Technol. 2020, 40, 158-167. [CrossRef]

24. Zhai, W.; Hu, L.; Geng, D.L.; Wei, B. Thermodynamic properties and microstructure evolution of ternary $\mathrm{Al}-10 \% \mathrm{Cu}-\mathrm{x} \% \mathrm{Sn}$ immiscible alloys. J. Alloys Compd. 2015, 627, 402-409. [CrossRef]

25. Costa, T.A.; Dias, M.; Freitas, E.S.; Casteletti, L.C.; Garcia, A. The effect of microstructure length scale on dry sliding wear behaviour of monotectic Al-Bi-Sn alloys. J. Alloys Compd. 2016, 689, 767-776. [CrossRef]

26. Cui, G.; Niu, M.; Zhu, S.; Yang, J.; Bi, Q. Dry-Sliding Tribological Properties of Bronze-Graphite Composites. Tribol. Lett. 2012, 48, 111-122. [CrossRef] 